\title{
KOMPETENSI DAN INTERSEKSI KOMPETENSI LULUSAN D-III BAHASA INGGRIS MINAT PROFESI ADMINISTRASI BISNIS DAN HUBUNGAN MASYARAKAT
}

\author{
WAHYU KARTIKA WIENANDA ${ }^{1}$, NUR ENDAH NUGRAHENI ${ }^{2}$, \\ ERLIN ESTIANA YUANTI3 \\ Program Studi Bahasa Inggris Sekolah Vokasi Universitas Gadjah Mada' \\ wahyu.wienanda@ugm.ac.id \\ Program Studi Bahasa Inggris Sekolah Vokasi Universitas Gadjah Mada ${ }^{2}$ \\ nurendah_nugraheni@ugm.ac.id \\ Program Studi Bahasa Inggris Sekolah Vokasi Universitas Gadjah Mada \\ erlin_estiana@ugm.ac.id
}

\begin{abstract}
Concrete and practical competencies matching the workforce needs have an essential role in constructing the employability of the graduates, especially during MEA era where the graduates are expected to compete internationally. To accommodate this purpose, D-III English SV-UGM provides a number of professional concentrations for the students, including Business Administration (BA) and Public Relation (PR) to give them practical skills that are applicable in the workforce. In light of this circumstance, the present research aims at remapping the graduate competencies to be mastered by the students of D-III English concentrating on BA and PR and revealing the intersections of the competencies. Library study, questionnaire administration, and interview were conducted to obtain the data from the stakeholders. The results show that the graduates concentrating in BA are highly expected to give excellent service to the clients and customers, to maintain documents and letters, and have a good archival knowledge. Meanwhile, the graduates with PR concentration should be able to have good communication skills and understanding about the computer and media use. Furthermore, the graduates from both concentrations are expected to perform Occupational Health and Safety Environment, and have a good interpersonal skill to enable them to work effectively with their colleagues.
\end{abstract}

Keywords: graduate competencies, business administration, public relation

\section{Intisari}

Kompetensi konkret dan praktis yang sesuai dengan kebutuhan dunia kerja memiliki peranan penting dalam membentuk kelayakan kerja para lulusan, terutama pada era MEA dimana mereka harus bersaing secara global. Program Studi D-III Bahasa Inggris SV-UGM merespon kondisi tersebut dengan menawarkan sejumlah minat profesi, termasuk minat profesi Administrasi Bisnis (Adbis) dan Hubungan Masyarakat (Humas) untuk membekali para peserta didik dengan keterampilan praktis yang aplikatif. Penelitian ini bertujuan memetakan kembali kompetensi yang harus dikuasai para lulusan Program Studi D-III Bahasa Inggris minat profesi Adbis dan Humas serta menguak irisan kompetensi kedua minat profesi tersebut. Studi pustaka, pemberian kuesioner, dan wawancara dilakukan guna mengumpulkan data dari para pemangku kepentingan. Hasil penelitian menunjukkan bahwa lulusan minat profesi Adbis harus menguasai keahlian pelayanan prima, pengaturan surat dan dokumen, serta pengarsipan dokumen. Sedangkan lulusan minat profesi Humas harus memiliki keterampilan komunikasi yang unggul dan keahlian menggunakan komputer dan media. Sebagai tambahan, lulusan dari kedua minat profesi tersebut juga harus menguasai dan melaksanakan prosedur Keselamatan dan Kesehatan Kerja (K3) serta memiliki hubungan interpersonal yang baik dengan rekan sejawat.

Kata Kunci: kompetensi lulusan, administrasi bisnis, hubungan masyarakat 


\section{Pendahuluan}

Sejak diterapkannya Masyarakat Ekonomi ASEAN (MEA) pada tahun 2015, persaingan untuk mendapatkan sebuah pekerjaan bukan lagi pada tataran nasional, namun pada pasar tenaga kerja ASEAN. Kebutuhan akan tenaga kerja ahli dan terampil pun kian meningkat dengan terbukanya pasar global di ASEAN. Kondisi ini dikuatkan oleh pendapat Tubsree dan Bunsong (2013) yang menyatakan bahwa MEA bertujuan untuk membangun sebuah pasar dan tempat produksi yang stabil, makmur, dan kompetitif serta terintegrasi secara ekonomi dengan adanya perputaran yang bebas pada barang, investasi, dan tenaga kerja terampil. Selain itu, Pane (2014) menyatakan bahwa ada 4 pilar pada MEA yang salah satunya adalah single market and production based atau terciptanya arus perdagangan bebas pada barang, jasa, investasi, pekerja terampil, dan modal. Dengan begitu, persaingan dalam memperoleh sebuah pekerjaan juga jauh lebih tinggi. Hal ini berlaku pula pada para lulusan perguruan tinggi (Silawati, Patria, dan Abzeni, 2015).

Menyadari hal itu, pendidikan vokasional berperan penting dalam mendidik dan menghasilkan sumber daya manusia yang terampil dan berkeahlian (Fikrianto, 2017). UNESCO pada tahun 2001 pada Catatan Rekomendasi atas Pendidikan Teknis dan Vokasional dan Pelatihan menyebutkan dengan adanya perkembangan besarbesaran pada ilmu pengetahuan, tekonologi, dan sosial-ekonomi, serta revolusi pada teknologi informasi dan komunikasi, pendidikan teknis dan vokasional menjadi aspek yang penting pada proses pendidikan di setiap negara (Education International, 2009). Hal ini dikarenakan pendidikan vokasional tidak hanya membekali peserta didik dengan informasi teoretis, melainkan juga keterampilan kerja. Pendidikan umum dan akademis membangun keterampilan analisis, pengetahuan, dan berpikir kritis, sedangkan pendidikan vokasional lebih memunculkan keahlian praktis (craftmanship), pengalaman praktis, dan pemecahan masalah (Education International, 2009). Kotsikis (dalam Mortaki, 2012) menyatakan bahwa istilah pendidikan vokasional secara umum mencakup segala jenis pendidikan yang bertujuan menguasai keahlian dari suatu profesi, seni, atau pekerjaan. Untuk itu, tidak cukup hanya dengan memberikan bekal keilmuan (knowledge) kepada 
mahasiswa, namun juga menyertakan bekal kompetensi profesional dan kinerja sebagai capaian lulusan dari pendidikan vokasional.

Sebagai penyedia jasa pendidikan vokasional, D-III Bahasa Inggris Sekolah Vokasi Universitas Gadjah Mada (SVUGM) tanggap atas kondisi persaingan global dengan tidak hanya memberikan bekal keilmuan bahasa kepada mahasiswa, melainkan juga menyediakan minat profesi bagi mahasiswanya dengan harapan mencetak lulusan yang siap kerja. Minat profesi tersebut di antaranya adalah Administrasi Bisnis dan Hubungan Masyarakat. Penyediaan minat profesi telah dilaksanakan sejak tahun ajaran 2012/2013, yang mana kurikulum tersebut telah diterapkan selama lima tahun.

Rahmawati dan Anggraini (2017) memaparkan bahwa kurikulum harus dipantau dan dievaluasi secara berkala guna menyesuaikan standar kompetensi lulusan dengan alumni dari tiap institusi pendidikan. Kesesuaian kurikulum, termasuk di dalamnya capaian lulusan, dengan kebutuhan para pemangku kepentingan dan pengguna lulusan merupakan hal yang sangat krusial dalam menentukan kualitas pelaksanaan kurikulum pada suatu lembaga (Aquino et al., 2015). Uraian para ahli tersebut mengindikasikan bahwa kurikulum Program Studi D-III Bahasa Inggris Tahun 2012 perlu dievaluasi guna meninjau kesesuaian antara capaian lulusan dengan kebutuhan pasar kerja. Berdasarkan panduan dari Direktorat Jenderal Pendidikan Tinggi yang diterbitkan pada tahun 2014, capaian lulusan handaknya mengacu pada kebijakan universitas dan program studi, masukan dari pemangku kepentingan, dan deskripsi Kerangka Kualifikasi Nasional Indonesia (KKNI) (Direktorat Jenderal Pendidikan Tinggi, 2014). Capaian lulusan inilah yang akan dikerucutkan menjadi kompetensi inti, kompetensi umum, dan kompetensi khusus yang sesuai dengan kebutuhan pasar kerja.

Pemetaan kompetensi ini dilakukan dalam rangka penyesuaian capaian lulusan program studi dengan kebutuhan pasar kerja dan KKNI. Selain pemetaan kompetensi, interseksi kompetensi juga diperlukan untuk mengetahui sejauh mana hubungan atau irisan kompetensi inti dari tiap minat profesi tersebut sebagai dasar penyajian mata kuliah wajib atau umum. Pemetaan kembali kompetensi inti serta interseksi kompetensi untuk minat profesi 
Administrasi Bisnis dan Hubungan Masyarakat bertujuan untuk menyesuaikan kompetensi dan keterampilan yang dibutuhkan pada dunia kerja, sebagai acuan pembekalan mata kuliah pada mahasiswa untuk meminimalisir adanya competency gap.

\section{Metodologi Penelitian}

Penelitian ini merupakan penelitian deskriptif kualitatif dengan menggunakan studi pustaka, skala rating, dan wawancara sebagai alat pengumpulan data. Studi pustaka KKNI dan hasil penelitian terdahulu dilakukan guna mendapatkan faktor kompetensi yang perlu dikuasai oleh mahasiswa dengan minat profesi Administrasi Bisnis dan Hubungan Masyarakat. Faktor kompetensi tersebut kemudian disusun menjadi daftar kompetensi berupa skala rating yang digunakan untuk mendapatkan balikan dari para pemangku kepentingan baik dari insituti swasta maupun milik pemerintah.

Skala rating menggunakan skala Likert 1-5, dimana rating 1 berarti sangat tidak penting, 2 berarti tidak penting, 3 berarti mungkin dibutuhkan, 4 berarti penting, dan 5 berarti sangat penting. Jumlah kompetensi pada skala rating tiap minat profesi berbeda sesuai dengan keahlian pada level 5 KKNI di tiap minat profesi serta tambahan dari pustaka lain yang terkait. Skala rating pada minat profesi Administrasi Bisnis terdiri dari 49 daftar kompetensi dan pada minat profesi Hubungan Masyarakat terdiri atas 54 daftar kompetensi. Skala rating disebarkan kepada 30 stakeholders yang berada di Yogyakarta, yaitu calon pengguna lulusan baik dari institusi swasta maupun dinas, alumni yang telah bekerja pada bidang terkait dengan kedua minat profesi, serta kolega yang telah bekerja pada bidang terkait. Hasil dari skala rating digunakan sebagai dasar pemetaan kompetensi awal dengan menyeleksi setidaknya 50\% dari total kompetensi untuk masing-masing minat profesi dengan nilai indeks tinggi.

Nilai indeks dihitung berdasarkan penghitungan yang diadaptasi dari Sudijono (2009) dengan menggunakan penghitungan rerata ideal dan standar deviasi ideal guna menentukan kelompok jawaban ke dalam lima kategori sesuai dengan pilihan dari angket skala Likert. Kemudian kompetensi yang diambil dan digunakan sebagai data untuk tahap wawancara merupakan kompetensi yang termasuk 
pada kategori sangat penting.

Pembagian kategori berdasarkan nilai rerata dijabarkan pada Tabel 1.

\begin{tabular}{|l|l|}
\hline \multicolumn{1}{|c|}{ Attitude Level } & \multicolumn{1}{c|}{ Score } \\
\hline Sangat penting & $4,2-5,0$ \\
\hline Penting & $3,4-4,1$ \\
\hline Netral & $2,7-3 \cdot 3$ \\
\hline Tidak penting & $1,8-2,6$ \\
\hline Sangat tidak penting & $1,0-1,7$ \\
\hline
\end{tabular}

Tabel 1. Kategori jawaban responden

(adaptasi dari Sudijono, 2009)

Setelah didapatkan pemetaan kompetensi awal berdasarkan kategori pada Tabel 1, wawancara dilakukan pada sepertiga dari responden (10 orang). Wawancara ini dilakukan sekitar 10 menit pada tiap responden guna mendapatkan masukan tambahan dan/atau afirmasi terkait dengan pemetaan kompetensi awal. Hasil wawancara berupa catatan yang kemudian dikelompokkan sebagai dasar perbaikan pada pemetaan kompetensi yang ada serta pengerucutan kompetensi menjadi 30\% dari total kompetensi awal. Dengan begitu, akan didapatkan pemetaan kompetensi final.

\section{Hasil dan Pembahasan}

Kompetensi minat profesi Administrasi Bisnis dan Hubungan Masyarakat dibagi ke dalam tiga kelompok kompetensi, yaitu kompetensi umum, kompetensi inti, dan kompetensi khusus. Kompetensi umum (generic competence) mencakup keterampilan dasar yang harus dikuasai oleh setiap lulusan pada masing-masing minat profesi seperti misalnya pengetahuan teknologi informasi dasar dan keterampilan dasar komunikasi. Sedangkan kompetensi inti mencakup kompetensi profesional yang harus dikuasai oleh lulusan pada tiap minat profesi. Kompetensi inti juga mencerminkan konten yang harus dipelajari oleh mahasiswa pada tiap minat profesi guna memenuhi standar keahlian pada tiap bidang. Selain itu, mahasiswa juga diberikan kompetensi khusus atau kompetensi pelengkap yang mendukung pelaksanaan pekerjaan nantinya.

\section{Kompetensi Minat Profesi Administrasi} Bisnis

Dari penyebaran angket diambil 26 kompetensi dari total 49 kompetensi terdaftar dengan nilai rerata yang tinggi 
dan termasuk pada kategori sangat penting dengan rentang rerata pada 4,2 hingga 5,0. Terdapat 5 kompetensi umum, 17 kompetensi inti, dan 4 kompetensi khusus yang masuk dalam kategori sangat penting untuk dikuasai oleh para lulusan dengan minat profesi Administrasi Bisnis. Kedua puluh enam kompetensi tersebut disajikan pada Tabel 2 sebagai hasil dari pemetaan tahap awal kompetensi.

Tabel 2. Pemetaan Tahap Awal dari Kompetensi Minat Profesi Administrasi Bisnis

\begin{tabular}{|c|c|}
\hline Jenis Kompetensi & Rerata \\
\hline \multicolumn{2}{|l|}{ Kompetensi Umum } \\
\hline $\begin{array}{l}\text { 1. Memberikan pelayanan kepada } \\
\text { pelanggan }\end{array}$ & 4,9 \\
\hline $\begin{array}{l}\text { 2. Mengaplikasikan keterampilan } \\
\text { dasar komunikasi }\end{array}$ & 4,63 \\
\hline 3. Berkomunikasi melalui telepon & 4,4 \\
\hline 4. Menggunakan peralatan kantor & 4,3 \\
\hline $\begin{array}{l}\text { 5. Bekerjasama dengan kolega dan } \\
\text { pelanggan }\end{array}$ & 4,3 \\
\hline \multicolumn{2}{|l|}{ Kompetensi Inti } \\
\hline 1. Melakukan prosedur administrasi & 4,8 \\
\hline $\begin{array}{l}\text { 2. Mampu bekerja di dalam tim untuk } \\
\text { mencapai tujuan organisasi }\end{array}$ & 4,8 \\
\hline $\begin{array}{l}\text { 3. Memiliki leadership yang baik dan } \\
\text { mampu memimpin kerja tim }\end{array}$ & 4,7 \\
\hline $\begin{array}{l}\text { 4. Menangani penerimaan } \\
\text { surat/dokumen }\end{array}$ & 4,7 \\
\hline $\begin{array}{l}\text { 5. Mengelola dan menjaga sistem } \\
\text { kearsipan }\end{array}$ & 4,63 \\
\hline 6. Memelihara data di komputer & 4,6 \\
\hline
\end{tabular}

\begin{tabular}{|c|c|c|}
\hline 7. & $\begin{array}{l}\text { Bekerja secara efektif dengan } \\
\text { orang lain }\end{array}$ & 4,53 \\
\hline 8. & $\begin{array}{l}\text { Menangani pengiriman } \\
\text { surat/dokumen }\end{array}$ & 4,43 \\
\hline 9. & $\begin{array}{l}\text { Mengelola layanan pelanggan } \\
\text { berkualitas }\end{array}$ & 4,43 \\
\hline 10. & $\begin{array}{l}\text { Berpikir secara praktis, logis, dan } \\
\text { sistematis dalam perencanaan dan } \\
\text { penyelesaian masalah }\end{array}$ & 4,43 \\
\hline 11. & $\begin{array}{l}\text { Menuntaskan aktivitas pekerjaan } \\
\text { sehari-hari }\end{array}$ & 4,4 \\
\hline 12. & $\begin{array}{l}\text { Membaca dalam bahasa Inggris } \\
\text { pada tingkat operasional } \\
\text { menengah }\end{array}$ & 4,37 \\
\hline 13. & $\begin{array}{l}\text { Bernegosiasi dengan kolega } \\
\text { maupun klien dengan baik }\end{array}$ & 4,3 \\
\hline 14. & Mengelola stress & 4,3 \\
\hline 15. & $\begin{array}{l}\text { Menulis dalam bahasa Inggris pada } \\
\text { tingkat operasional menengah } \\
\text { (menulis surat, laporan, memo, dan } \\
\text { email) }\end{array}$ & 4,27 \\
\hline 16. & $\begin{array}{l}\text { Mengakses dan penarikan data } \\
\text { computer }\end{array}$ & 4,2 \\
\hline 17. & Menggunakan teknologi kantor & 4,2 \\
\hline \multicolumn{3}{|c|}{ Kompetensi Khusus } \\
\hline 1. & $\begin{array}{l}\text { Mengikuti prosedur K3 } \\
\text { perkantoran }\end{array}$ & 4,47 \\
\hline 2. & Menjaga keamanan K3 perkantoran & 4,47 \\
\hline 3. & $\begin{array}{l}\text { Memiliki hubungan interpersonal } \\
\text { yang baik }\end{array}$ & 4,4 \\
\hline 4. & $\begin{array}{l}\text { Menjaga kebersihan peralatan di } \\
\text { tempat kerja }\end{array}$ & 4,37 \\
\hline
\end{tabular}

Sumber: Data skala rating

Dua puluh enam kompetensi pada pemetaan awal kemudian menjadi bahan diskusi dengan para narasumber guna 
menjaring masukan untuk pemetaan kompetensi tahap akhir.

Berdasarkan masukan dari hasil wawancara, sebanyak empat kompetensi dapat dihilangkan dari kerangka kompetensi minat profesi Administrasi Bisnis. Kompetensi tersebut mencakup kemampuan membaca dan menulis menggunakan bahasa Inggris, kemampuan menyelesaikan tugas seharihari, kemampuan menggunakan peralatan kantor, keahlian menggunakan teknologi kantor, dan kemampuan menjaga kebersihan peralatan di tempat kerja. Penghapusan kompetensi bahasa Inggris pada kerangka kompetensi minat profesi adalah karena kemampuan tersebut menjadi capaian lulusan yang utama dari program studi D-III Bahasa Inggris di mana para lulusan harus mampu menguasai keterampilan berbahasa Inggris setara dengan level B2 dari Common European Framework of Reference for Languages (CEFR), sebagaimana tercantum pada dokumen kurikulum program studi D-III Bahasa Inggris SV-UGM (2012).

Selain keterampilan berbahasa Inggris, kemampuan menyelesaikan tugas sehari-hari, menggunakan peralatan kantor dan menjaga kebersihan peralatan di tempat kerja dipandang sebagai kemampuan dasar teknis yang perlu dikuasai oleh setiap orang, tidak harus peserta didik dengan minat profesi Administrasi Bisnis saja. Hodges dan Burchell (2003) menemukan bahwa kemampuan dasar teknis seperti tersebut di atas mendapat peringkat rendah pada penelitian mereka karena para penyedia lapangan kerja beranggapan bahwa kemampuan tersebut dapat dipelajari sembari bekerja. Hal ini juga dikuatkan oleh temuan dari Bolli dan Renold (2015) di mana keahlian proses manajemen tidak begitu signifikan untuk dikuasai selama masa pendidikan karena keahlian tersebut dapat dipelajari atau dikuasai ketika bekerja.

Kompetensi $\mathrm{K}_{3}$ dapat dirangkum menjadi satu, yaitu mengikuti prosedur dan menjaga keamanan $\mathrm{K} 3$ perkantoran. Hal ini karena ketika seseorang mampu mengikuti prosedur yang berlaku di tempat kerja, secara bersamaan orang tersebut telah menjaga keamanan kerja, di mana $\mathrm{K}_{3}$ merupakan prioritas utama bagi pekerja pada tiap institusi (Markkanen, 2004). Masukan terkait dengan kompetensi $\mathrm{K}_{3}$ juga diberikan pada pengelompokannya. Alih-alih masuk pada kompetensi khusus, kemampuan terkait dengan $\mathrm{K}_{3}$ 
seharusnya dikelompokkan sebagai kompetensi umum karena pada dasarnya seseorang bekerja harus sesuai dengan prosedur yang ada sebagaimana yang telah diatur pada Undang-Undang No 1/1970 tentang Keselamatan Kerja dan Undang-Undang No 23/1992 tentang Kesehatan.

Kemampuan berkomunikasi melalui telepon juga dapat digabungkan dengan kompetensi yang lebih umum terkait dengan teknik komunikasi, yaitu mengaplikasikan keterampilan dasar komunikasi. Berdan (2012) juga menyatakan bahwa keterampilan berkomunikasi merupakan keahlian yang esensial dan diperlukan oleh lulusan Administrasi Bisnis. Menez (2014) dalam penelitian tracer study lulusan Bisnis Administrasi yang dilakukannya juga menemukan bahwa keahlian komunikasi sangatlah relevan digunakan dalam pekerjaan para lulusan. Temuan dari Bolli dan Renold (2015) juga menunjukkan bahwa keahlian berkomunikasi menduduki peringkat pertama pada soft skill yang harus dikuasai oleh lulusan Administrasi Bisnis.

Keterampilan pengarsipan yang juga dirasa penting untuk dikuasai dapat sedikit diperluas tidak hanya mencakup arsip konvensional, namun juga mencakup arsip digital sehingga kompetensi ini dapat dikombinasikan dengan kemampuan memelihara data di komputer. Terlebih lagi, kemampuan penerimaan dan pengiriman surat/dokumen dapat digabungkan menjadi satu.

Dari pengurangan dan penggabungan kompetensi pada pemetaan tahap awal, didapatlah pemetaan kompetensi minat profesi Administrasi Bisnis tahap final dengan rincian: empat kompetensi umum, sebelas kompetensi inti, dan satu kompetensi khusus. Pemetaan kompetensi tersebut dijabarkan pada Tabel 3.

Tabel 3. Kompetensi Minat Profesi Administrasi Bisnis

\begin{tabular}{|ll|}
\hline \multicolumn{2}{|l|}{ Kompetensi Umum } \\
\hline 1. & Memberikan pelayanan kepada pelanggan \\
\hline 2. & $\begin{array}{l}\text { Mengaplikasikan keterampilan dasar } \\
\text { komunikasi }\end{array}$ \\
\hline 3. & Bekerjasama dengan kolega dan pelanggan \\
\hline 4. & $\begin{array}{l}\text { Mengikuti prosedur dan menjaga keamanan } \\
\text { K3 perkantoran }\end{array}$ \\
\hline
\end{tabular}

\begin{tabular}{|l|l|}
\hline \multicolumn{2}{|l|}{ Kompetensi Inti } \\
\hline 1. Melakukan prosedur administrasi \\
\hline mencapai tujuan organisasi \\
\hline 3. Memiliki leadership yang baik dan mampu \\
memimpin kerja tim \\
\hline 4. Menangani penerimaan dan pengiriman
\end{tabular}




\begin{tabular}{|l|}
\hline \multicolumn{2}{|l|}{ surat/dokumen } \\
5onvensional dan digital \\
\hline 6. Bekerja secara efektif dengan orang lain \\
\hline 7. Mengelola layanan pelanggan berkualitas \\
\hline 8. Berpikir secara praktis, logis, dan sistematis \\
dalam perencanaan dan penyelesaian \\
masalah \\
\hline 9. Bernegosiasi dengan kolega maupun klien \\
dengan baik \\
\hline 10. Mengelola stress data dari \\
\hline 11. Mengakses dan penarikan data \\
computer
\end{tabular}

\section{Kompetensi Khusus}

1. Memiliki hubungan interpersonal yang baik

Sumber: Data hasil wawancara

Menariknya, dari data yang dikumpulkan baik melalui skala rating dan wawancara, kemampuan terkait dengan pengelolaan keuangan, khususnya keterampilan menyiapkan anggaran dan mengatur kas, tidak termasuk dalam kategori sangat penting. Sedangkan, kemampuan penyiapan anggaran termasuk dalam kategori penting, dan keterampilan mengatur kas termasuk pada kategori netral. Hal ini seperti menyiratkan bahwa soft skill tampak lebih dibutuhkan dalam dunia kerja. Ini didukung dengan hasil temuan Menez (2014) dan Buenviaje, Mundo, Añonuevo, dan Martinez (2015) di mana keahlian kewiraswastaan dan yang berkaitan dengan keuangan merupakan faktor pendukung yang relevan bagi lulusan dalam melakukan pekerjaannya, tapi tidak terlalu signifikan.

\section{Kompetensi Minat Profesi Hubungan Masyarakat}

Skala rating yang disebarkan untuk mendapatkan balikan tentang kompetensi umum, inti, dan khusus dari minat profesi Hubungan Masyarakat memiliki 53 daftar kompetensi, dan akan diambil sebanyak 30 kompetensi dengan nilai rerata tinggi yang termasuk pada kategori sangat penting untuk dimasukkan pada pemetaan tahap awal. Kompetensi tersebut dijabarkan pada Tabel 4 .

Tabel 4. Pemetaan Tahap Awal dari

Kompetensi Minat profesi Hubungan

Masyarakat

\begin{tabular}{|c|c|}
\hline Jenis Kompetensi & Rerata \\
\hline \multicolumn{2}{|l|}{ Kompetensi Umum } \\
\hline $\begin{array}{l}\text { 1. Membuat dan mengakses } \\
\text { dokumen di komputer }\end{array}$ & 4,8 \\
\hline $\begin{array}{l}\text { 2. Merancang dan mengembangkan } \\
\text { dokumen, laporan dan lembar kerja } \\
\text { dengan komputer }\end{array}$ & 4,6 \\
\hline $\begin{array}{l}\text { 3. Menyampaikan presentasi lisan } \\
\text { dalam bahasa Inggris }\end{array}$ & 4,23 \\
\hline \multicolumn{2}{|l|}{ Kompetensi Inti } \\
\hline 1. Melakukan komunikasi dalam & 4,83 \\
\hline
\end{tabular}




\begin{tabular}{|c|c|}
\hline situasi krisis & \\
\hline 2. Membuat siaran pers & 4,83 \\
\hline 3. Melaksanakan community relations & 4,77 \\
\hline 4. Mengelola isu negative & 4,77 \\
\hline $\begin{array}{l}\text { 5. Membuat proposal } \\
\text { program/kegiatan kehumasan }\end{array}$ & 4,77 \\
\hline $\begin{array}{l}\text { 6. Menjalin hubungan dengan pihak } \\
\text { media }\end{array}$ & 4,77 \\
\hline 7. Melaksanakan konferensi pers & 4,57 \\
\hline 8. Menyeleksi proposal sponsorship & 4,57 \\
\hline $\begin{array}{l}\text { 9. Pertukaran informasi lisan dalam } \\
\text { bahasa Inggris }\end{array}$ & 4,53 \\
\hline $\begin{array}{l}\text { 10. Memiliki kemampuan membaca } \\
\text { informasi dalam bahasa Inggris } \\
\text { pada tingkat operasional } \\
\text { menengah }\end{array}$ & 4,53 \\
\hline 11. Membuat laporan program & 4,53 \\
\hline $\begin{array}{l}\text { 12. Memetakan media yang dipakai } \\
\text { untuk kepentingan kehumasan }\end{array}$ & 4,5 \\
\hline $\begin{array}{l}\text { 13. Menyusun data dan informasi } \\
\text { strategis }\end{array}$ & 4,47 \\
\hline $\begin{array}{l}\text { 14. Membuat publikasi internal dan } \\
\text { eksternal }\end{array}$ & 4,43 \\
\hline $\begin{array}{l}\text { 15. Membuat materi ringkasan } \\
\text { (briefing material) }\end{array}$ & 4,43 \\
\hline 16. Melakukan lobby dan negosiasi & 4,4 \\
\hline $\begin{array}{l}\text { 17. Melakukan komunikasi dengan } \\
\text { kelompok tertentu }\end{array}$ & 4,4 \\
\hline $\begin{array}{l}\text { 18. Melaksanakan pendekatan human } \\
\text { relation }\end{array}$ & 4,33 \\
\hline $\begin{array}{l}\text { 19. Menulis dalam bahasa Inggris } \\
\text { (mengirim email, membuat artikel } \\
\text { berita, editorial) pada tingkat } \\
\text { operasional menengah }\end{array}$ & 4,3 \\
\hline 20. Membuat company profile & 4,3 \\
\hline 21. Melaksanakan aktivitas protokoler & 4,3 \\
\hline 22. Melakukan presentasi & 4,3 \\
\hline
\end{tabular}

\begin{tabular}{|c|c|}
\hline $\begin{array}{l}\text { 23. Mendesain dan menyesuaikan } \\
\text { media pemasaran }\end{array}$ & 4,27 \\
\hline \multicolumn{2}{|l|}{ Kompetensi Khusus } \\
\hline $\begin{array}{l}\text { 1. Menyusun prioritas, jadwal } \\
\text { perencanaan proyek, dan } \\
\text { memenuhi target/deadline }\end{array}$ & 4,43 \\
\hline 2. Melaksanakan Master of Ceremony & 4,23 \\
\hline 3. Melaksanakan fungsi moderator & 4,23 \\
\hline
\end{tabular}

Sumber: Data skala rating

Berdasarkan data yang dijabarkan pada Tabel 4, dapat dilihat bahwa pendapat para stakeholders cukup bervariasi dalam menentukan kompetensi mana yang lebih penting untuk dikuasai oleh para peserta didik program studi D-III Bahasa Inggris Minat Profesi Hubungan Masyarakat. Hal ini terlihat dari sebaran data yang cukup lebar, yaitu 4,83 untuk kompetensi dengan nilai rerata tertinggi, yaitu kemampuan melakukan komunikasi dalam situasi kritis dan membuat siaran pers, dan 2,97 untuk nilai rerata terendah, yaitu kemampuan untuk menyelenggarakan kompetisi. Hanya saja, kompetensi yang masuk dalam 50 persen teratas memiliki nilai rerata serendah-rendahnya 4,23, yaitu empat kompetensi termasuk menulis dalam bahasa Inggris, membuat company profile, melaksanakan aktivitas protokoler, dan melakukan presentasi. 
Selain itu, jika diamati secara mendetil, kompetensi minat profesi humas yang dianggap penting lebih banyak mencakup tentang komunikasi, penggunaan media, pemasaran, dan menjalin hubungan. Ini telah sesuai dengan hasil survey yang dilakukan pada Public Relations Society of America (PRSA) terkait dengan profesi kehumasan tahun 2015. Seorang pegawai kehumasan memiliki enam peran utama, yaitu sebagai fasilitator, penghubung, komunikan, pemberi pengaruh, konselor strategis, dan marketer, dan dalam menjalankan peranannya dia akan membutuhkan pengetahuan tentang media dan penggunaannya, menjalin hubungan dengan berbagai pihak termasuk pihak media, keterampilan komunikasi yang handal, dan pemikiran kritis (Public Relation Society of America, 2011). Temuan dari penelitian Kerr dan Proud (2005) juga menunjukkan bahwa perekrut memberikan rating setinggi 90\% terhadap pentingnya penguasaan keterampilan komunikasi.

Hasil pemetaan awal kemudian dikerucutkan menjadi 18 kompetensi melalui wawancara dengan stakeholders dan dijadikan kerangka pemetaan kompetensi tahap akhir untuk minat profesi Hubungan Masyarakat yang ditampilkan pada Tabel 5.

Tabel 5. Kompetensi Minat Profesi Hubungan Masyarakat

\section{Kompetensi Umum \\ 1. Merancang dan mengembangkan dokumen, laporan dan lembar kerja dengan komputer}

\begin{tabular}{|c|c|}
\hline & Kompetensi Inti \\
\hline 1. Melakukan komunikasi dalam situasi krisis & - $\quad$ Melakukan komunikasi dalam situasi krisis \\
\hline & $\begin{array}{l}\text { Membuat siaran pers dan melakukan } \\
\text { konferensi pers }\end{array}$ \\
\hline & Mengelola isu negatif \\
\hline & $\begin{array}{l}\text { Membuat proposal program/kegiatan } \\
\text { kehumasan }\end{array}$ \\
\hline & . Menjalin hubungan dengan pihak media \\
\hline & Menyeleksi proposal sponsorship \\
\hline & Membuat laporan program \\
\hline & $\begin{array}{l}\text { Memetakan media yang dipakai untuk } \\
\text { kepentingan kehumasan }\end{array}$ \\
\hline & Menyusun data dan informasi strategis \\
\hline & o. Membuat publikasi internal dan eksternal \\
\hline & $\begin{array}{l}\text { 1. Membuat materi ringkasan (briefing } \\
\text { material) }\end{array}$ \\
\hline & $\begin{array}{l}\text { 2. Melaksanakan pendekatan human dan } \\
\text { community relations }\end{array}$ \\
\hline & 3. Membuat company profile \\
\hline & 4. Melaksanakan aktivitas protokoler \\
\hline & 5. Melaksanakan fungsi moderator \\
\hline & $\begin{array}{l}\text { 6. Mendesain dan menyesuaikan media } \\
\text { pemasaran }\end{array}$ \\
\hline
\end{tabular}

\section{Kompetensi Khusus}

1. Menyusun prioritas, jadwal perencanaan proyek, dan memenuhi target/deadline

Sumber: Data hasil wawancara 
Pada Tabel 5 terlihat bahwa ada beberapa kompetensi yang dihilangkan. Kompetensi pertama yang dieliminasi adalah kompetensi terkait dengan keterampilan berbahasa Inggris baik secara lisan maupun tertulis, seperti yang dilakukan pada pemetaan kompetensi pada sub-bahasan sebelumnya. Hal ini dikarenakan kemampuan bahasa Inggris merupakan kompetensi wajib dari program studi DIII Bahasa Inggris. Selain itu, kemampuan melakukan lobi dan negosiasi, menjadi Master of Ceremony serta kemampuan melakukan presentasi juga dihilangkan sebab kedua kemampuan ini dapat dilebur dan disertakan di dalam mata kuliah berbicara, terutama berbicara pada publik atau public speaking. Kemampuan tersebut akan menjadi muatan atau capaian pembelajaran pada mata kuliah berbicara.

Terkait dengan kompetensi umum, yaitu membuat dan mengakses dokumen di komputer, penarikan dokumen dan merancang dan mengembangkan dokumen, laporan, dan lembar kerja dengan komputer memiliki kemiripan, sehingga dapat digabung menjadi satu pada kompetensi yang mencakup area keahlian yang lebih luas. Keterampilan tersebut termasuk pada keahlian ilmu teknologi, di mana para lulusan diharapkan menjadi orang yang technology literate. Alexander (2004) menyatakan bahwa para praktisi Hubungan Masyarakat tengah menghadapi tantangan dari pelbagai alat komunikasi komputer, sehingga pada masa mendatang mereka harus menguasai penggunaan teknologi, terutama teknologi digital seperti website, aplikasi online, dan berbagai perangkat lunak lainnya. Selain itu, mereka juga diharapkan mampu melakukan riset online, sehingga perubahan pada kurikulum pendidikan Hubungan Masyarakat perlu diubah dengan menitikberatkan penguasaan teknologi. Sejalan dengan pendapat tersebut, Public Relation Society of America (2011) pada dokumennya juga menyatakan bahwa para pekerja humas setidaknya memerlukan sepuluh area pengetahuan dan keterampilan tambahan, termasuk di dalamnya menggunakan teknologi informasi secara efisien. Michael dan Gorpe (2017) juga menemukan bahwa literasi media digital merupakan hal yang penting untuk dikuasai praktisi Hubungan Masyarakat pada saat ini (era modern).

Kemampuan terkait dengan menjalin hubungan dengan pihak lain, 
seperti orang perseorangan, komunitas, dan kelompok tertentu juga dapat digabung menjadi satu kompetensi inti, yaitu melakukan pendekatan human and community relations yang merupakan kompetensi utama dari minat profesi hubungan masyarakat. Tugas praktisi maupun konsultan Hubungan Masyarakat adalah memberikan informasi dan melakukan pendekatan pada khalayak dan lingkungan (Sinaga, 2010).

Kompetensi terakhir yang dapat digabungkan adalah kemampuan membuat siaran pers dan melakukan konferensi pers karena kedua kompetensi ini berkaitan dengan hal yang serupa, yaitu memberikan informasi pada khalayak umum.

Interseksi Kompetensi Minat Profesi Administrasi Bisnis dan Hubungan Masyarakat

Dari data yang telah dikumpulkan, terlihat bahwa kedua minat profesiAdministrasi Bisnis dan Hubungan Masyarakat-memiliki beberapa interseksi (irisan) kompetensi. Interseksi kompetensi merupakan beberapa kompetensi atau keahlian dari tiap minat profesi, yang harus dipelajari dan dikuasai oleh seluruh mahasiswa
Program Studi D-III Bahasa Inggris SVUGM dari seluruh minat profesi.

Irisan kompetensi yang paling utama adalah kemampuan berkomunikasi baik secara lisan maupun tertulis menggunakan bahasa Inggris yang setara dengan tingkat operasional menengah. Hal ini sesuai dengan capaian lulusan yang dicanangkan pada dokumen kurikulum program studi D-III Bahasa Inggris SV-UGM (2012), di mana para lulusan dari program studi diharapkan memiliki kemampuan berbahasa Inggris setara dengan level B2 (vantage) pada Common European Framework of Reference for Languages (CEFR). Pada tingkat ini, seseorang telah dianggap sebagai pengguna Bahasa Inggris yang mandiri dan mampu menggunakan Bahasa Inggris dengan lancar dan spontan untuk mengemukakan ide pada berbagai topik. Untuk lebih rincinya, berdasarkan dokumen Using the CEFR: Principles of Good Practice oleh Universitas Cambridge, pengguna Bahasa Inggris pada tingkat B2 mampu memahami ide pokok dari teks yang kompleks baik mengenai topik abstrak maupun konkret termasuk diskusi teknis pada bidang keahliannya. Selain itu, mereka juga diharapkan mampu berinteraksi secara 
lancar dan spontan serta dapat berkomunikasi dengan penutur asli Bahasa Inggris tanpa kesulitan (2011). Namun, kemampuan bahasa Inggris yang dimaksud masih memerlukan kekhususan konten atau keterampilan agar dapat mencakup keahlian komunikasi lisan, presentasi, korespondensi, dan negosiasi yang berguna bagi minat profesi Administrasi Bisnis, dan Hubungan Masyarakat sebagaimana yang didapat dari responden melalui wawancara. Kemampuan berkomunikasi secara umum juga merupakan bagian dari irisan kompetensi yang signifikan dari kedua minat profesi.

Keahlian informasi dan teknologi juga merupakan salah satu irisan kompetensi yang harus dikuasai oleh mahasiswa dari tiap minat profesi. Keahlian ini mencakup keterampilan menggunakan komputer, terutama dalam hal membuat, mengembangkan dan menyimpan dokumen atau lembar kerja. Keterampilan ini penting untuk dikuasai terkait dengan perkembangan teknologi yang perlu diikuti demi memiliki daya saing secara global di dunia kerja. Temuan ini juga sesuai dengan temuan pada penelitian yang dilakukan oleh Zaman (2015) di mana keterampilan informasi dan teknologi juga dianggap penting bagi para penyedia lapangan kerja. Terlebih lagi, pada jaman di mana teknologi berkembang pesat seperti saat ini. Keahlian menggunakan komputer pada era komputerisasi seperti saat ini sangatlah penting.

Sebagai tambahan dari keterampilan menggunakan teknologi, khususnya mengoperasikan komputer, lulusan juga diharapkan mampu melaksanakan prosedur Keselamatan dan Kesehatan Kerja (K3) pada bidang pekerjaan masing-masing. Hal ini menunjukkan pentingnya $\mathrm{K} 3$ karena setiap institusi diharuskan memiliki standar prosedur pelaksanaan kegiatan kerja dan perlindungan keselamatan kerja bagi para pegawainya. Sebagaimana yang diutarakan oleh Suma'mur (2005), indikator K3 diharuskan menjadi kewajiban perharian perusahaan di dalam beroperasi dan mempekerjakan karyawannya. Pelaksanaan prosedur $\mathrm{K}_{3}$ penting dalam mewujudkan tempat kerja aman dan sehat guna meningkatkan produktivitas kerja (International Labour Organization, 2013).

Irisan kompetensi terakhir adalah kompetensi yang berkaitan erat dengan 
soft skill, khususnya hubungan interpersonal. Para lulusan D-III Bahasa Inggris dari minat profesi Administrasi Bisnis dan Hubungan Masyarakat dituntut untuk mampu menjalin hubungan baik dengan kolega, mampu bekerja dalam tim, dan mampu bekerja sama secara efektif dengan rekan sejawat. Hasil ini mendukung penelitian yang dilakukan oleh Hodges dan Burchell (2003), di mana keahlian interpersonal menempati urutan keempat dari sepuluh kompetensi dengan penilaian tertinggi. Selain itu, OECD (2010, dalam Murgor, 2013) juga menyuarakan bahwa keterampilan dasar, termasuk di dalamnya soft skills, sangatlah dibutuhkan pada pasar tenaga kerja.

\section{Kesimpulan}

Dari pembahasan yang telah dijabarkan, dapat ditarik tiga kesimpulan utama. Pertama, peserta didik dengan minat profesi Administrasi Bisnis diharapkan mampu memberikan pelayanan prima kepada klien dan pelanggan serta mampu berkomunikasi dengan baik. Hal ini dikarenakan mereka merupakan pegawai garis depan yang dapat memengaruhi citra sebuah institusi. Selain itu, berkaitan dengan hal administrasi, mereka juga diharapkan mampu menyimpan dokumen dan surat penting serta memiliki keahlian pengarsipan yang baik.

Kedua, peserta didik dengan minat profesi Hubungan Masyarakat dituntut untuk memiliki kemampuan komunikasi yang baik dengan berbagai pihak, termasuk kolega, klien, maupun pihak media. Komunikasi menjadi hal utama untuk menjalin hubungan baik dengan berbagai pihak guna menjaga citra sebuah institusi. Selain itu, mereka juga harus menguasai penggunaan komputer dan media publikasi.

Kesimpulan terakhir adalah terkait dengan irisan kompetensi pada kedua minat profesi, di mana para peserta didik dituntut untuk mampu melaksanakan prosedur Kesehatan, Keselamatan, dan Keamanan Kerja (K3) serta memiliki keterampilan interpersonal yang baik untuk menjalin hubungan kerja efektif dengan rekan kerja sejawat.

\section{Daftar Pustaka}

Alexander, D. (2004). Changing the Public Relations Curriculum: A New Challenge for Educators. Prism2. Retrieved Oktober 12, 2017, from http://citeseerx.ist.psu.edu/viewdoc/ 
download?doi=10.1.1.671.9479\&rep=r

ep1\&type=pdf

Aquino, AB., Punongbayan, EJ., Macalaguim, LP., Bauyon, SM., Rodriguez Jr., RA., dan Quizon, GR. (2015). Teacher Education Graduate Tracer Study from 2010 to 2014 in One State University in Batangas Philippines. Asia Pacific Journal of Multidisciplinary Research, 3(5).

Berdan, SN. (2012). Top Skills MBA Grads Need for Success. Retrieved from http://www.huffingtonpost.com/stac ie-nevadomski-berdan/mba-jobs_b_1126299.html

Bolli, Thomas, dan Renold, Ursula. (2015). Comparative Advantages of School and Workplace Environment in Competence Acquisition: Empirical Evidence from a Survey among Professional Tertiary Education and Training Students in Switzerland. KOF Working Papers, KOF Swiss Economic Institute, ETH Zurich, 389. Retrieved from http://dx.doi.org/10.3929/ethza-010480922

Direktorat Jenderal Pendidikan Tinggi. (2014). Panduan Penyusunan Capaian Pembelajaran Lulusan Program Studi. Retrieved October 8, 2017 from http://belmawa.ristekdikti.go.id/dev/
wp-content/uploads/2015/11/6A-

Panduan-Penyusunan-CP.pdf

Education International.

(2009)

Literature Review: Vocational

Education and Training. Retrieved

October 8, 2017.

Fikrianto, M. (2017). Pendidikan Vokasi untuk Menghasilkan SDM yang berdaya saing. Retrieved October 8, 2017 from http://www.republika.co.id/ berita/jurnalisme-warga/kabar/ 17/02/05/okw2ky396-pendidikanvokasi-untuk-menghasilkan-sdm-yangberdaya-saing

Hodges, D, and Burchell, N. (2003). Business Graduate Competencies: Employers' Views on Importance and Performance. Asia-Pacific Journal of Cooperative Education, 4(2), 16-22.

International Labour Organization. (2013). Keselamatan dan Kesehatan Kerja di Tempat Kerja: Sarana Untuk Produktivitas. Pedoman Pelatihan untuk Manajer dan Pekerja Modul 5. Jakarta: ILO.

Kerr, G.F., dan Proud, B. (2005). Hiring Graduates: Perpectives from Advertising and Public Relations Employers. Conference paper in ANZMAC 2005: Marketing Education. Retrieved March 20, 2018 from 
https://eprints.qut.edu.au/25715/1/257

15_kerr_2006001276.pdf

Markkanen, PK. (2004). Kertas Kerja 9:

Keselamatan dan Kesehatan Kerja di

Indonesia. Manila: International

Labour Organization. Retrieved

October 9, 2017.

Menez, N.L. (2014). Tracer Study of the

Masters in Business Administration

(MBA) Graduates from 2008-2012.

Asia Pacific Journal of Educaion, Arts and Sciences, Vol. 1, No. 1, pp.14-18.

Michael, N. \& Gorpe, T.S. (2017). Public

Relations for the Next Generation:

Middle East Public Relations Association (MEPRA)'s Engagement with Students. Learning and Teaching in Higher Education: Gulf Perspectives, 14(2).

Mortaki, S. (2012). The Contribution of Vocational Education and Training in the Preservation and Diffusion of Cultural Heritage in Greece: The Case of the Specialty "Guardian of Museums and Archaeological Sites". International Journal of Humanities and Social Science 2(24), December 2014, 52-58.

Murgor, TK. (2013). Relationship between Technical and Vocational Acquired Skills and Skills Required in Job Market: Evidence from TVET
Institutions, Uasin Gishu County, Kenya. Journal of Education and Practice, 4(19), 77-83.

Pane, ES. (2014). Tinjauan Kesiapan SDM / Tenaga Kerja Indonesia Menghadapi Masyarakat Ekonomi ASEAN. Retrieved October 9, 2017 from www.pusdiklat.kemenperin.go.id

Program Studi D-III Bahasa Inggris Sekolah Vokasi UGM. (2012). Buku Kurikulum Program Studi D-III Bahasa Inggris Sekolah Vokasi Universitas Gadjah Mada.

Rahmawati, D., \& Anggraini, AD. (2017). Evaluasi Program Kurikulum Berdasarkan Standar Isi, Standar Proses, dan Standar Kompetensi Lulusan di SDN Pisangan Timur 10 Pagi. Jurnal Pendidikan Ekonomi dan Bisnis, Vol. 5(1), Maret 2017, 35-50.

Sinaga, E.H. (2010). Konsultan Public Relations pada Program Nasional Pemberdayaan Masyarakat (PNPM) Mandiri Perkotaan. Jurnal Fisip. Retrieved October 8, 2017 from http://ejurnal.fisipuntirta.ac.id/index. php/JRK/article/view/82/73

Sudijono, A. (2009). Pengantar Statistik Pendidikan. Jakarta: Rajawali.

Suma'mur, P.K. (2005). Keselamatan Kerja dan Pencegahan Kecelakaan. Jakarta: PT. Toko Gunung Agung. 
Tubsree, C., \& Bunsong, S. (2013).

Practice and Working Paper:

Curriculum Development of Vocational

Teacher Education within the Context

of ASEAN Integration Process.

Shanghai: RCP.

Undang-Undang Republik Indonesia No

1/1970 tentang Keselamatan Kerja

Undang-Undang Republik Indonesia No

23/1992 tentang Kesehatan.

Public Relation Society of America.

(2011). White Paper: The Public

Relation Professionals in 2015.

Retrieved October 8, 2017 from

http://apps.prsa.org/AboutPRSA/Doc

uments

Zaman, L. (2015). Competencies Needed

For 2015: Employers Preference In

Business Graduate Selection. Review

of Integrative Business \& Economics

Resesearch, Vol 4(3) 22. 